\title{
Ubiquitous Computing Frameworks and Location Sensing Technologies: A Survey
}

\author{
Swetha K. B \\ Assistant Professor \\ Department of ISE \\ RR Institute of Technology \\ Chikkabanavara \\ Bengaluru -560 090, Karnataka
}

\author{
G. C. Banu Prakash, PhD \\ Professor and HoD \\ Department of CSE , \\ Sir MV Institute of Technology, \\ KrishnaDeveraya Nagar \\ Bengaluru- 562 157, Karnataka
}

\begin{abstract}
Technological advances in miniaturized devices, sensors and wireless networking have led increasingly to the integration of sensors and devices with users and physical environment, leading to ubiquitous computing systems. Ubiquitous computing (ubicomp) supports a widely networked infrastructure of a multitude of sensing and computing devices. It ensures that information is accessible everywhere and moves the interaction beyond the desktop and into the real world with a special attention to activities of everyday human life. Ubiquitous computing framework provides a structure and set of libraries to design and develop customized ubiquitous computing applications. In this paper a detailed survey of papers related to different approaches of Ubiquitous Computing Frame works and location sensing technologies is done.
\end{abstract}

\section{General Terms}

Sensors, Ubiquitous Computing and Frame Work.

\section{Keywords}

Ubiquitous Computing Framework, Location Sensing Technologies, Location Detection.

\section{INTRODUCTION}

Ubiquitous computing (ubicomp) [Weiser 1988] is a model of human-computer interaction, in which information processing has been thoroughly integrated into everyday objects and activities. It is the method of enhancing computer use by making any computers available throughout the physical environment but making them effectively invisible to the user.

Mark Wiser in his articles [1,5] related to : "The Computer for the $21^{\text {st }}$ Century" highlighted the future trend of merging of profound technologies into everyday life. Today the ubicomp applications are diverse in nature ranging from small applications that help commuters track train and bus schedules to smart laboratories, smart museums, instrumented classrooms, etc. The ubiquitous computing environment may contain many devices with which user interact. These devices include:

- $\quad$ Laptop Computers

- Smart Phones

- Handheld devices including personal digital assistants (PDAs), mobile phones, pagers and digital cameras.

- Wearable devices such as smart watches, google glass, oculus rift, tile, gps shoes, fin ring, etc.
- Medical wearables such as fitness band, air Louisville, itBra, kardia mobile and kardia band, uv sense, etc.

- Devices embedded in appliances such as washing machines, hi-fi systems, cars and refrigerators.

- Appliances and Devices embedded in Smart Home, Smart Class Room, Smart Road, Smart Shopping Center, Smart Hospital, Smart Vehicles, Smart Agriculture Crop Monitoring System, etc.

Some of the ubiquitous computing applications and projects designed and developed earlier are discussed below:

1. Ubiquitous Health Care [6]: A patient or elderly person is continuously monitored with wearable health sensors placed on the patient's body. An interface collects data and sends this data to the monitoring system. Due to the seamless connectivity characteristic and context aware behavior of ubiquitous devices the interface remains connected by exploiting the available technologies like RFID, Bluetooth, ZigBee, GPS, etc.

2. Ubiquitous Navigation System [7]: The software provides the information like location, user context (static situation, dynamic situation, static intention and dynamic intention), train operating information, etc. It makes use of technologies like GPS, GPRS, Wireless LAN, Mobile IP, RFID and Bluetooth.

3. E-Class Room: Classroom 2000 [8] is an attempt to study the impact of Ubicomp in teaching and learning activities. The system has feature like: can capture different activities in the class room, can integrate all format of lecture notes in a sequence, can assist teacher for evaluation, can assist for collaborative teaching and learning, etc.

4. Cyber Guide [9]: The project is focused on exploiting the portable computers to assist users making use of physical and cyber spaces. As a subjective study mobile and hand-held technology-based tour guide was developed using GPS positioning systems. It makes use of location information to track the user / suggest establishments and maintains history of places visited, for future.

5. Easy Living [10]: At Microsoft Research, the Ubiquitous Computing Group has created a system called Easy Living that is a prototype of architecture and technologies for ubiquitous computing. The Easy Living system demonstrates many of the capabilities of ubiquitous computing, including mobile, wireless computing with migratory programs; an intelligent environment with context-awareness and locationsensitive computing; and disaggregated computing. 
6. Stanford iroom [11]: A test bed of smart room with spatial, socially aware, deep physically integrated and coordinated autonomous systems. The room is fixed with multiple large embedded Displays, Laptops and Heterogeneous handheld devices.

7. Labscape [12]: Ubiquitous biology Lab with Sensors and PCs. Labscape is a smart environment that was designed to improve the experience of people who work in a cell biology laboratory.

Change in user context causes the actions in ubiquitous computing environment. For example, user entry inside the living room can cause the lights on/off, ac on/off, TV on /off, windows curtains to close/open, etc., depending on the user's context like mood, activity, time, temperature, etc.

One of the distinguishing features of Ubiquitous Computing is that the computation is a part and parcel of everyday life. The computing services required for user depends on user's social and personal context. Thus, the ubiquitous computing systems can provide more meaningful and useful services provided the systems are context aware in nature.

Ubiquitous Systems are a store house of sensors and devices without context aware computing. It is the context aware methodologies which makes ubiquitous systems aware of situations of interest, enhances services to users, automates systems and reduces obtrusiveness, customizes and personalizes applications.

Albrecht Schmidt in his report [13] highlights the importance of context aware computing as: "Context is essential for building usable Ubiquitous Computing systems that respond in a way that is anticipated by the user". Definitions given by earlier works and standard dictionaries agree on the key idea that contexts describe situations. This definition clearly states that context is always bound to an entity. The entity itself is regarded as something that is relevant to the interaction between a user and an application. The user-application relationship is rooted in the traditional notion of an application, but not limited to it.

Dey and Abowd (2000) have also confirmed this by defining context as: "Any information that can be used to characterize the situation of an entity. An entity is a person, a place, or a physical or computational object that is considered relevant to the interaction between a user and an application, including the user and application themselves.' $[14,15]$
The context can be categorized into different types based on the information they carry. Context may be Computing context, network context, user context, device context, sensor context, physical context, time context, etc. User context provides the information related to user like location, name, role, priority, activity, mood and other useful user's information.

Context aware computing finds its origin as early as 1992 when the, Want et al., introduced the Active Badge Location System which is considered to be one of the first context aware applications. The application used infrared technology to determine the user location. The information was used to forward the phone calls to a telephone close to the user. Based on the location context a couple of location aware tourist guides was developed in the middle of 1990s (Abowd et al., 1997; Sumiet al., 1998; Chevrest et al., 2000). All the context aware applications designed during mid of 1990s were based on location context. In 1994 Schilit and Theimer used the term context aware to describe the context as location, identities of nearby peoples, objects and changes to those objects. In 1997 Rayen et al., used the term context to describe the user's location, environment, identity and time. A Dey and Abowd (2000) moved a step forward and used the term context as information to describe the overall situation of entities. Zimmerman (2007) et al., described the context in terms of five categories: individually, activity, location, time and relations. Bolchini et al., (2009) defined context as the set of variables that may be of interest for an agent and that influence it actions.

\section{LITERATURE SURVEY}

The proposed research direction involves in design and development of Ubiquitous computing framework using location sensing technologies. In this direction a survey is made on Ubiquitous Computing Frameworks and Location sensing technologies.

\section{a. Survey Related to Ubiquitous Computing Frame Work:}

A frame work provides a structure and common methods to make the life of application developer much easier for building flexible, scalable and maintainable applications. Ubiquitous Computing Framework provides a structure and set of methods/libraries to design and develop ubiquitous computing applications.

Table 1: Ubiquitous Computing Frameworks

\begin{tabular}{|l|l|l|}
\hline \multicolumn{1}{|c|}{ Framework } & \multicolumn{1}{|c|}{ Approach } & \multicolumn{1}{c|}{ Features } \\
\hline $\begin{array}{l}\text { A General-Purpose Framework for } \\
\text { Ubiquitous Computing [16] }\end{array}$ & Peer to Peer Communication & $\begin{array}{l}\text { Decentralized, Scalable, Distributed, Self } \\
\text { Organizing, Location independent, Adaptive } \\
\text { Protocol Stack, Fault Tolerant, Application } \\
\text { Specific Approach. }\end{array}$ \\
\hline $\begin{array}{l}\text { A Service Discovery Framework for } \\
\text { Ubiquitous Computing [17] }\end{array}$ & $\begin{array}{l}\text { Using Mapping table of Global Manage } \\
\text { Server (GMS) and Local Manage Server } \\
\text { (LMS) }\end{array}$ & $\begin{array}{l}\text { Flexible and Scalable Architecture to } \\
\text { provide local and remote services. }\end{array}$ \\
\hline $\begin{array}{l}\text { Hybrid Rule and Neural Network } \\
\text { Based Framework for Ubiquitous } \\
\text { Computing [18] }\end{array}$ & $\begin{array}{l}\text { Hybrid Rule and Neural Network. } \\
\text { Knowledge Representation using Frames, } \\
\text { Fuzzy Rules and Linguistic Variables. }\end{array}$ & Stand Alone and Loosely Coupled Model \\
\hline $\begin{array}{l}\text { A context-aware framework } \\
\text { supporting complex ubiquitous } \\
\text { scenarios with Augmented Reality } \\
\text { enabled [19] }\end{array}$ & $\begin{array}{l}\text { Modeling scenarios as a finite state machine } \\
\text { transitions being controlled by context } \\
\text { information. The Framework is designed } \\
\text { with Augmented Reality architecture to } \\
\text { enable augmented interaction in context- } \\
\text { aware applications. }\end{array}$ & $\begin{array}{l}\text { Lightweight and flexible context } \\
\text { awareness. } \\
\text { Support for multi-state applications. } \\
\text { Higher interaction and user friendly }\end{array}$ \\
\hline An Energy-Efficient Context & $\begin{array}{l}\text { Data reduction approach to lower the } \\
\text { An }\end{array}$ & \multicolumn{1}{|c|}{ Energy Efficient } \\
\hline
\end{tabular}




\begin{tabular}{|c|c|c|}
\hline $\begin{array}{l}\text { Management Framework (CMF) for } \\
\text { Ubiquitous Systems [20] }\end{array}$ & $\begin{array}{l}\text { amount of data sent to CMF over the } \\
\text { network, minimizing the energy } \\
\text { consumption and the network traffic of } \\
\text { sensor-rich CMF }\end{array}$ & $\begin{array}{ll}\text { - } & \begin{array}{l}\text { Maximize lifetime of monitoring } \\
\text { platform }\end{array} \\
\text { - } & \begin{array}{l}\text { Improved Availability of context aware } \\
\text { services }\end{array}\end{array}$ \\
\hline $\begin{array}{l}\text { BaaS-4US: A Framework to Develop } \\
\text { Standard Backends as a Service for } \\
\text { Ubiquitous Applications [21] }\end{array}$ & $\begin{array}{l}\text { Top-down approach for the implementation } \\
\text { and deployment of Web Services generated } \\
\text { from behavioral models. } \\
\text { Layered Architecture Comprising: API } \\
\text { Access, User Level Security, Role Based } \\
\text { Security and Service Model }\end{array}$ & $\begin{array}{l}\text { - Can deploy the web services in the } \\
\text { cloud } \\
\text { - Automatically generate the API } \\
\text { documentation } \\
\text { - Creation of the data model on which } \\
\text { services act. } \\
\text { - Communication services using REST } \\
\text { and SOAP protocol. }\end{array}$ \\
\hline $\begin{array}{l}\text { A Context Realization Framework for } \\
\text { Ubiquitous Applications with } \\
\text { Runtime Support [22] }\end{array}$ & $\begin{array}{l}\text { Dynamic Run Time Context based Service } \\
\text { Recommendation }\end{array}$ & $\begin{array}{l}\text { - Developers can specify their context } \\
\text { requirements at design time and } \\
\text { automatically realize them at runtime } \\
\text { in a soft integration fashion. }\end{array}$ \\
\hline $\begin{array}{l}\text { Mobile Agent based Framework for } \\
\text { Mobile Ubiquitous Application } \\
\text { Development [23] }\end{array}$ & $\begin{array}{l}\text { An event-based communication paradigm } \\
\text { designed specifically for ad-hoc wireless } \\
\text { environments is incorporated, which } \\
\text { supports loose coupling between sensors, } \\
\text { actuators and application components }\end{array}$ & $\begin{array}{l}\text { The framework allows developers to fuse } \\
\text { data from disparate sensors, represent } \\
\text { application context, and reason efficiently } \\
\text { about context, without the need to write } \\
\text { complex code }\end{array}$ \\
\hline $\begin{array}{l}\text { Context-aware ubiquitous } \\
\text { framework services using JADE- } \\
\text { OSGI integration framework [24] }\end{array}$ & $\begin{array}{l}\text { This paper presents a context aware } \\
\text { ubiquitous approach based on lightweight } \\
\text { coupling between multi-agent JADE system } \\
\text { and OSGi framework }\end{array}$ & $\begin{array}{l}\text { Dynamically configurable and extensible } \\
\text { due to the heterogeneity and the mobility of } \\
\text { smart appliances and users. }\end{array}$ \\
\hline $\begin{array}{l}\text { A Distributed Location Based } \\
\text { Service Framework of Ubiquitous } \\
\text { Computing [25] }\end{array}$ & $\begin{array}{l}\text { The framework uses an extensible web } \\
\text { crawler to get the necessary information } \\
\text { from the Internet and are turned to location- } \\
\text { aware information by connecting them with } \\
\text { their locations which are extracted from } \\
\text { themselves }\end{array}$ & $\begin{array}{l}\text { - The service framework provides } \\
\text { information based on users search } \\
\text { requests and location of infotainment } \\
\text { and user at any time. } \\
\text { Provides the traditional navigation } \\
\text { service and runs on real data. }\end{array}$ \\
\hline
\end{tabular}

b. Survey Related to Location Sensing Technologies:

The three technologies areas that are required in order to realize the design and development of Ubiquitous Computing frameworks are 1. Sensing technology (particularly location sensing) 2. Context Aware Computing and 3. Network Technology.

Sensing technologies are essential to capture the user context like activity, mood, time, location, etc. Location sensing and capturing is one the important sensing technology that is essential for designing Ubicomp Frameworks. Most of the user required services depends on his /her location.

Authors Jeffrey Hightower and Gaetano Borriello [26] in their research paper presented a detailed study of location sensing methods and technologies that can be used in Ubiquitous computing framework as illustrated in Table 2 and Table 3.

Table 2: Types of Location Sensing Methods and Examples [26]

\begin{tabular}{|c|c|c|c|}
\hline Type & Sub Categories & Approaches & Examples \\
\hline \multirow{4}{*}{$\begin{array}{l}\text { Triangulation: Uses the } \\
\text { geometric properties of } \\
\text { triangles to compute } \\
\text { object location. }\end{array}$} & \multirow[t]{3}{*}{$\begin{array}{ll}\text { Lateration: } & \text { Measures } \\
\text { distance from } & \text { reference } \\
\text { points } & \end{array}$} & $\begin{array}{l}\text { Direct: Direct measurement of } \\
\text { distance uses a physical action or } \\
\text { movement. }\end{array}$ & Robotic Movement \\
\hline & & $\begin{array}{l}\text { Time-of-Flight: Measuring the } \\
\text { time it takes to travel between the } \\
\text { object and point } \mathrm{P} \text { at a known } \\
\text { velocity }\end{array}$ & $\begin{array}{l}\text { GPS, Active Bat, Cricket, Bluesoft } \\
\text { and PulsON. }\end{array}$ \\
\hline & & $\begin{array}{l}\text { Attenuation: Measuring the } \\
\text { intensity of an emitted signal. } \\
\text { Calculate based on send and } \\
\text { receive strength, attenuation } \\
\text { varies based on environment }\end{array}$ & SpotON \\
\hline & $\begin{array}{l}\text { Angulation: } \\
\text { Angles form reference } \\
\text { position. }\end{array}$ & $\begin{array}{l}\text { Angles are used for determining } \\
\text { the position of an object. }\end{array}$ & 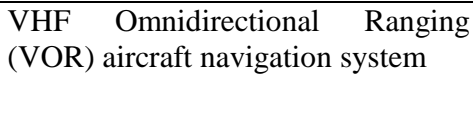 \\
\hline
\end{tabular}




\begin{tabular}{|c|c|c|c|}
\hline $\begin{array}{lrr}\text { Scene } & \text { Analysis: } & \text { Uses } \\
\text { features of a scene } \\
\text { observed from } & \text { a } \\
\text { particular point. } & \end{array}$ & & $\begin{array}{l}\text { Compares scenes to reference } \\
\text { scenes } \\
\text { - Images } \\
\text { - Electromagnetic readings }\end{array}$ & $\begin{array}{lll}\text { Microsoft Research } & \text { RADAR } \\
\text { location system }\end{array}$ \\
\hline \multirow{3}{*}{$\begin{array}{l}\text { Proximity: The object's } \\
\text { presence is sensed using } \\
\text { a physical phenomenon } \\
\text { with limited range } \\
\text { (nearby). }\end{array}$} & $\begin{array}{l}\text { Detecting physical } \\
\text { contact }\end{array}$ & $\begin{array}{l}\text { Using pressure sensors, touch } \\
\text { sensors, and capacitive field } \\
\text { detectors }\end{array}$ & Touch Mouse \\
\hline & $\begin{array}{l}\text { Monitoring wireless } \\
\text { cellular access points. }\end{array}$ & $\begin{array}{l}\text { Monitoring when a mobile device } \\
\text { is in range of one or more access } \\
\text { points in a wireless cellular } \\
\text { network } \quad \text { is another } \\
\text { implementation of the proximity } \\
\text { location technique }\end{array}$ & $\begin{array}{l}\text { Active Badge } \text { Location } \\
\text { Xerox ParcTAB System. }\end{array}$ \\
\hline & $\begin{array}{l}\text { Observing automatic ID } \\
\text { systems. }\end{array}$ & $\begin{array}{l}\text { If the device scanning the label, } \\
\text { interrogating the tag, or } \\
\text { monitoring the transaction has a } \\
\text { known location, the location of } \\
\text { the mobile object can be inferred. }\end{array}$ & $\begin{array}{l}\text { Uses automatic identification } \\
\text { systems such as credit card point-of- } \\
\text { sale terminals, computer login } \\
\text { histories, land-line telephone } \\
\text { records, electronic card lock logs, } \\
\text { and identification tags such as } \\
\text { electronic highway E-Toll systems, } \\
\text { UPC product codes, and injectable } \\
\text { livestock identification capsules }\end{array}$ \\
\hline
\end{tabular}

Table 3: Location Sensing Technologies [27]

\begin{tabular}{|c|c|c|c|c|}
\hline Technology Name & Technique & Properties & $\begin{array}{c}\text { Accuracy and } \\
\text { Precision }\end{array}$ & Limitations \\
\hline GPS & Radio time of lateration & $\begin{array}{l}\text { Physical, Absolute and } \\
\text { LLC }\end{array}$ & $\begin{array}{l}1-5 \text { meters }(95- \\
99 \%)\end{array}$ & Not indoors \\
\hline Active Badges & $\begin{array}{l}\text { Diffuse infrared cellular } \\
\text { proximity }\end{array}$ & $\begin{array}{l}\text { Symbolic, Absolute and } \\
\text { Recognition }\end{array}$ & Room size & $\begin{array}{l}\text { Sunlight \& fluorescent } \\
\text { interference with infrared }\end{array}$ \\
\hline Active Bats & $\begin{array}{l}\text { Ultrasonic Time of } \\
\text { flight lateration }\end{array}$ & $\begin{array}{l}\text { Physical Absolute and } \\
\text { Recognition }\end{array}$ & $9 \mathrm{~cm}(95 \%)$ & Required ceiling sensor grids \\
\hline $\begin{array}{l}\text { VHE Omni } \\
\text { Directional } \\
\text { Ranging }\end{array}$ & Angulation & $\begin{array}{l}\text { Physical, Absolute and } \\
\text { LLC }\end{array}$ & $\begin{array}{l}1 \circ \text { radial } \\
(\approx 100 \%)\end{array}$ & $\begin{array}{l}\text { 30-140 nautical miles line of } \\
\text { sight }\end{array}$ \\
\hline Motion Star & $\begin{array}{l}\text { Scene Analysis, } \\
\text { Lateration }\end{array}$ & $\begin{array}{l}\text { Physical, Absolute and } \\
\text { Recognition }\end{array}$ & $\begin{array}{l}1 \mathrm{~mm}, 1 \mathrm{~ms}, 0.1^{\circ} \\
(\text { nearly } 100 \%)\end{array}$ & $\begin{array}{l}\text { Control unit tether, precise } \\
\text { installation }\end{array}$ \\
\hline Cricket & Proximity, Lateration & $\begin{array}{l}\text { Symbolic, Absolute, } \\
\text { Relative and LLC }\end{array}$ & $\begin{array}{l}4 \times 4 \mathrm{ft} . \text { regions } \\
(\approx 100 \%)\end{array}$ & $\begin{array}{l}\text { No central management, receiver } \\
\text { computation }\end{array}$ \\
\hline MSR RADAR & $\begin{array}{l}802.11 \mathrm{RF} \text { scene } \\
\text { analysis \& triangulation }\end{array}$ & $\begin{array}{l}\text { Physical, Absolute and } \\
\text { LLC }\end{array}$ & $3-4.3 \mathrm{~m}(50 \%)$ & Wireless NICs required \\
\hline PinPoint 3D-iD & RF lateration & $\begin{array}{l}\text { Physical, Absolute and } \\
\text { Recognition }\end{array}$ & $1-3 m$ & Proprietary, 802.11 interference \\
\hline $\begin{array}{l}\text { Avalanche } \\
\text { Transceivers }\end{array}$ & $\begin{array}{l}\text { Radio signal strength } \\
\text { proximity }\end{array}$ & Physical and Relative & $\begin{array}{l}\text { Variable, } 60- \\
80 \mathrm{~m} \text { range }\end{array}$ & $\begin{array}{l}\text { Short radio range, unwanted } \\
\text { signal attenuation }\end{array}$ \\
\hline Easy Living & Vision, triangulation & $\begin{array}{l}\text { Symbolic, Absolute and } \\
\text { Recognition }\end{array}$ & Variable & Ubiquitous public cameras \\
\hline Smart Floor & $\begin{array}{l}\text { Physical contact } \\
\text { proximity }\end{array}$ & $\begin{array}{l}\text { Physical Absolute and } \\
\text { Recognition }\end{array}$ & $\begin{array}{l}\text { Spacing of } \\
\text { pressure sensors } \\
(100 \%)\end{array}$ & $\begin{array}{l}\text { Recognition may not scale to } \\
\text { large populations }\end{array}$ \\
\hline $\begin{array}{l}\text { Automatic ID } \\
\text { Systems }\end{array}$ & Proximity & $\begin{array}{l}\text { Symbolic, Absolute, } \\
\text { Relative and Recognition }\end{array}$ & $\begin{array}{l}\text { Range of } \\
\text { sensing } \\
\text { phenomenon } \\
\text { (RFID typically } \\
i 1 \mathrm{~m})\end{array}$ & Must known sensor locations \\
\hline Wireless Andrew & 802.11 cellular & Symbolic, Absolute and & 802.11 cell size & Wireless NICs required, RF cell \\
\hline
\end{tabular}




\begin{tabular}{|l|l|l|l|l|}
\hline & proximity & Recognition & $\begin{array}{l}(\approx 100 \mathrm{~m} \text { indoor, } \\
1 \mathrm{~km} \text { free space }\end{array}$ & geometries \\
\hline E911 & Triangulation & $\begin{array}{l}\text { Physical, Absolute and } \\
\text { Recognition }\end{array}$ & $\begin{array}{l}150-300 \mathrm{~m} \\
(95 \%)\end{array}$ & Only where cell coverage exists \\
\hline SpotON & Ad hoc lateration & $\begin{array}{l}\text { Physical, Relative and } \\
\text { Recognition }\end{array}$ & $\begin{array}{l}\text { Depends on } \\
\text { cluster size }\end{array}$ & $\begin{array}{l}\text { Attenuation less accurate than } \\
\text { time-of-flight }\end{array}$ \\
\hline
\end{tabular}

\section{CONCLUSIONS}

The proposed research work is to design and development of Ubiquitous Computing Framework using Location sensing technology. In this perspective a literature survey was made to understand the different approaches followed by the researchers and different sensing technologies available. The proposed framework shall be designed such that it will provide a structure and set of methods/libraries which can be used to write a user centric program for the following:

1. To capture the live data (location, time, day, network, user id, user activity, light intensity, temperature, weather conditions, etc.)

2. To recognize the user context dynamically through integrating live data semantically

3. To provide the services suitable to user context using suitable machine learning algorithms.

As a subjective study one of the following case study shall be considered for developing the prototype of the frame work:

1. Navigation Systems

2. Tourist Guide System

3. Smart Room

Following steps will be adapted sequentially for implementing the proposed framework.

1. Mathematical Modeling of the proposed framework and its components.

2. To identify Machine Learning Techniques required to recognize the dynamic context and action recommendation.

3. Design and Full Stack Implementation of the proposed Frame Work and its Components

a. User Interface

b. Middle Ware (User context sensitive recommendation System using ML)

c. Back End (User service repository for training, testing and validation)

4. Developing Ubiquitous Computing Applications (Smart Living System / Tourist Guide, etc.) using the developed Framework.

\section{REFERENCES}

[1] Mark Weiser, "The Computer for the 21st Century", Scientific American Ubicomp Paper, Published in Newsletter, ACM SIGMOBLE Mobile Computing and Communications Review-Special issues dedicated to Mark Weiser, doi:10.1145/329124.329124.329126 http://www.ubiq.com/hypertext/weiser/SciAmDraft3.htm 11991.

[2] M. Weiser, "Some Computer Science Issue in ubiquitous Computing", Communications of the ACM ,36(7), 1993, pp .74-84.
[3] Mark Weiser and John Seely Brown. "The Coming Age of Calm Technology", October 1996 http://www.ubiq.com/hypertext/weiser/acmfuture2endnot e.html.

[4] Mark Weiser. Open House, March 1996. http://www.ubiq.com/ hypertext/weiser/wholehouse.doc.

[5] Mark Weiser. Ubiquitous Computing, March 1996. http://www.ubiq.com/hypertext/weiser/UbiHome.html;

[6] Sriram, Natarajan, "An ubiquitous healthcare system using a wearable shirt for a smart home a prior study", published in proceedings of IEEE EMBS conference on Biomedical Engineering and Sciences (IECBES), Dec 2010,pages 205 -209, doi:10.1109/IECBES.2010.742229

[7] Wang, Yu-Ren, "Ubiquitous Navigation Based on Physical Maps and GPS", published in proceedings of International Symposium on Computer, Consumer and Control (IS3C), June-2012, Pages:101-105, DOI:101109/ IS3C.2012.35

[8] https://www.cc.gatech.edu/fce/c2000/overview/

[9] Gregory D. Abowd, et al., "Cybergude: a mobile context aware tour guide", Published in Journal of Wireless Networks - Special Issue: mobile computing and networking, Volume 3 Issue 5, Oct.1997, Pages 421-33, doi :10.123/A:1019194325861

[10] Steve Shafer, John Krumm, etal., "Easy Living: Technologies for Intelligent Environments", Published in Proceeding of HUC ' 00 Proceedings of the $2^{\text {nd }}$ international symposium on Handheld and Ubiquitous Computing, pages 12-29, ISBN :3-540-41093-7,2000.

[11] J. Borchers, M. Ringel, etal., "Stanford interactive workspaces: a framework for physical and graphical user interface prototyping", Published in Journal of IEEE Wireless Communications, Volume 9 Issue 6, December 2002, Pages 64-69, IEEE Press USA, doi:10.1109/MWC.2002.1160083

[12] Arnstein, Larry, "Labscape: a smart environment for the cell biology laboratory", Published in IEEE Pervasive Computing Magazine, July-Sept 2002, Volume 1, Pages 13-21doi:10.1109/MPRV.2002.1037717

[13] Albert Schmidt, "Ubiquitous Computing - Computing in Context", Ph.D Thesis Submitted to Lancaster University, November 2002.

[14] Dey, A. K., and Abowd, G. D. 2000, "Towards a Better Understanding of Context and Context-Awareness". In Proceedings of the Workshop on The What, Who, Where, When, and How of Context-Awareness within CHI'00, 1-12.

[15] Bettini.C., Brdiczka.O., Henricksen.K., Indulska.J., Nicklas.D., Ranganathan.A., and Riboni.D.,2010, "A survey of context modelling and reasoning techniques", DOI: 10.1016/j.pmcj.2009.06.002 Document Type: 
Article, Pervasive and Mobile Computing, Volume 6, Issue 2, April 2010, Pages 161-180,ISSN: 15741192.

[16] Stevenson, G. and Nixon, P. and Ferguson, R.I. (2003), "A general purpose programming framework for ubiquitous computing environments. In: Ubisys: System Support for Ubiquitous Computing Workshop (UbiCom)",2003-10-12, url: http://ubisys.cs.uiuc.edu/ papers /general-purpose-framework.pdf

[17] Xiaoguang Gu, Hongzhou Shi, Jian Ye, Zhenmin Zhu,“A Service Discovery Framework for Ubiquitous Computing", Eighth International Conference on Parallel and Distributed Computing, Applications and Technologies, DOI:10.1109/PDCAT.2007.69 Source:IEEE-Xplore, $175-176$

[18] Andrey V. Gavrilov, "Hybrid Rule and Neural Network based Framework for Ubiquitous Computing" Published in: 2008 Fourth International Conference on Networked Computing and Advanced Information Management, DOI: 10.1109/NCM.2008.129, Print ISBN: 978-0-76953322-3,Publisher: IEEE,Conference Location: Gyeongju, South Korea.

[19] Jinxue Zhang; Yuhong Sheng; Wei Hao; Patricia P. Wang; Phil Tian ; Kai Miao ; Cynthia K. Pickering, "A context-aware framework supporting complex ubiquitous scenarios with Augmented Reality enabled", Published in: 5th International Conference on Pervasive Computing and Applications, DOI: 10.1109/ICPCA.2010.5704077, Print ISBN: 978-1-4244-9144-5, url: https://ieeexplore.ieee.org/ document/5704077

[20] Vinicius Bezerra; Misael C. Junior ; Olga Valeria ; Constantino D. Neto; Liliam Leal ; Marcus Lemos , Nazim Agoulmin, Raimir Holanda," An Energy-Efficient Context Management Framework for Ubiquitous Systems", Published in: 2013 IEEE 10th International Conference on Ubiquitous Intelligence and Computing and 2013 IEEE 10th International Conference on Autonomic and Trusted Computing

[21] Francisco Carranza-Garc'1a, Carlos Rodr'iguezDom'inguez , BaaS-4US: A Framework to Develop
Standard Backends as a Service for Ubiquitous Applications, Published in : 2016 15th International Conference on Ubiquitous Computing and Communications and 2016 8th International Symposium on Cyberspace and Security, DOI 10.1109/IUCCCSS.2016.11, Page s: 23 - 30

[22] Jian Zhu, Hung Keng Pung, Mohammad Oliya, and Wai Choong Wong, National University of Singapore," A Context Realization Framework for Ubiquitous Applications with Runtime Support", Published in : 0163-6804/11/\$25.00 (c) 2011 IEEE, IEEE Communications Magazine - September 2011 , Pages : $132-141$

[23] Seungkeun Lee," Mobile Agent based Framework for Mobile Ubiquitous Application Development", Published in: 2010 International Conference on Information Science and Applications, DOI: 10.1109 /ICISA.2010.5480563, Print ISSN: 2162 9048, https://ieeexplore.ieee.org/document/5480563

[24] Faouzi Sebbak, Aicha Mokhtari, Abdelghani Chibani, Yacine Amirat, "Context-Aware ubiquitous framework services Using JADE-OSGI integration framework “, Published in: 2010 International Conference on Machine and Web Intelligence, DOI: $10.1109 /$ ICMWI.2010.5647900, Print ISBN: $978-$ 1-4244-8608-3, https://ieeexplore.ieee.org/document/5647900

[25] Weifeng Lv, Fei Wang, Yuan Zhang, Tongyu Zhu," A Distributed Location Based Service Framework of Ubiquitous Computing", 2010 First International Conference on Networking and Distributed Computing, DOI 10.1109/ICNDC.2010.1

[26] Jeffrey Hightower and Gaetano Borriello, “ Location Sensing Techniques"

[27] Jeff rey Hightower and Gaetano Borriello ," Location Systems for Ubiquitous Computing", Published in Journal of Computer, Volume 34 Issue 8 , Agust 2001, Pages 57-66, IEEE Computer Society Press , DOI : $10.1109 / 2.940014$ 